\title{
EVALUATION OF THE IMMUNOEXPRESSION OF COX-1, COX-2 AND p53 IN CROHN'S DISEASE
}

\author{
Mônica ROMER0 ${ }^{1}$, Ricardo ARTIGIANI' ${ }^{1}$, Henrique COSTA ${ }^{1}$, Celina Tizuko Fujiyama OSHIMA', \\ Sender MISZPUTEN ${ }^{2}$ and Marcello FRANCO ${ }^{1}$
}

\begin{abstract}
Background - Crohn's disease accompanied by nonspecific or idiopathic ulcerative proctocolitis corresponds to a condition called intestinal inflammatory disease. The immunoexpression of cyclooxygenase 2 (COX-2) in Crohn's disease becomes more marked with progression of the disease and the presence of wild-type p53 suppresses the transcription of COX-2. Aims - To investigate the immunoexpression of cyclooxygenase $1(\mathrm{COX}-1), \mathrm{COX}-2$ and 553 in Crohn's ileocolitis and to correlated this expression with clinical and histopathological parameters. Methods - Forty-five cases of Crohn's disease, 16 cases of actinic colitis (diseased-control group) and 11 cases without a history of intestinal disease (normal control group) were studied. Hematoxylin-eosin-stained sections were submitted to histopathological analysis and the immunohistochemical expression of COX-1, COX-2 and p53 was evaluated by the streptavidin-biotin-peroxidase method. Results - Sixty percent of the Crohn's disease patients were women and $40 \%$ were men, with $75.5 \%$ whites and $25.5 \%$ non-whites. The disease involved the terminal ileum in $44.5 \%$ of cases, ileum in $33.3 \%$, colon in $20 \%$ and duodenum-ileum in $2.2 \%$. A significant association was observed between COX-2 immunoreactivity and age $\leq 40$ years. Histopathological analysis of Crohn's disease samples showed mild or moderate crypt distortion ( $57.8 \%$ and $35.6 \%$ of cases), atrophy (6.6\%), mild, moderate and marked chronic inflammation (46.7\%, 26.7\% and 20\%), acute inflammatory activity (93.3\%), ulceration (24.4\%), mucin depletion (37.8\%), Paneth's cells (24.4\%), intraepithelial lymphocytes (93.3\%), and subepithelial collagen (6.7\%). In the CD group, COX-1 immunoreactivity in epithelial and inflammatory cells was observed in $26.7 \%$ and $22.2 \%$ of cases, respectively. COX-2 immunoreactivity was detected in epithelial cells in $68.9 \%$ of cases and in inflammatory cells in $46.7 \%$. A marginal difference in COX-2 reactivity was observed between epithelial and inflammatory cells in association with acute inflammatory activity and increase in intraepithelial lymphocytes. Comparison of the date among the threes groups (Crohn's disease, actinic colitis and normal controls) showed a higher proportion of cases presenting COX-2 immunoreactivity in inflammatory cells in the Crohn's disease group. No p53 reactivity was observed in all cases. Conclusions - COX-2 immunoexpression is high in Crohn's disease, which suggest a possible role of the protein in the pathogenesis of the inflammation. The absence of epithelial dysplasia in all Crohn's disease samples was correlated with the lack of expression of $\mathrm{p} 53$.
\end{abstract}

HEADINGS - Cyclooxygenase 1. Cyclooxygenase 2. Genes, p53. Crohn disease.

\section{INTRODUCTION}

Crohn's disease $(\mathrm{CD})$ is characterized by chronic inflammation, which may occur at any level of the digestive tract and which progresses with unpredictable outbreaks of exacerbation and remission ${ }^{(42)}$. The disease was first described by Crohn et al. ${ }^{(1)}$, in 1932. The etiopathogenesis of CD remains obscure and is believed to be multifactorial ${ }^{(7,29)}$.

In genetically predisposed individuals, the intestinal flora represents an environmental factor that may act as the trigger of an inflammatory process. Products secreted by microorganisms of the normal flora induces an increased in the permeability of epithelial cells of the intestinal mucosa; consequently an increased number of receptors for these antigens create conditions for an inadequate immunoinflammatory response. The loss of tolerance to antigens of the commensal bacterial flora seems to be the central event in the physiopathology of intestinal inflammatory disease, a condition comprising $\mathrm{CD}$ and the nonspecific or idiopathic ulcerative proctocolitis. This loss of tolerance is due to genetic mutations in the proteins responsible for the recognition of these antigens. In $\mathrm{CD}$, mutations in the NOD2/CARD15 gene located on chromosome 16 are considered to be the predisposing event for the development and maintenance of the chronic inflammatory process of the disease ${ }^{(9)}$.

Two classes of enzymes, cyclo- and lipoxygenases, are responsible for the synthesis of arachidonic acid metabolites, also known as eicosanoids; the first group

Departaments of ${ }^{1}$ Pathology and ${ }^{2}$ Gastroenterology, Paulista Medical School, Federal University of São Paulo State, São Paulo, SP, Brasil.

Correspondence: Dr. Marcello Franco - Departamento de Patologia - EPM/UNIFESP - Rua Botucatu, 740, Vila Clementino - 04023-062 - São Paulo, SP, Brasil. E-mail: mfranco@patologia.epm.br 
catalyses the synthesis of prostaglandins and thromboxanes, and the second group is involved in the synthesis of leukotrienes and lipoxins $^{(3,6)}$. Cyclooxygenase (COX), an enzyme important for the synthesis of prostaglandins, is present in three isoforms. COX-1 shows low or constitutive expression in a variety of tissues ${ }^{5,23,}$ 44). COX-2 is highly inducible in response to cellular activation by hormones, proinflammatory cytokines, growth factors and tumor promoters ${ }^{(41,44)}$. COX-3, which is encoded by the same gene as the COX-1 isoform, has been demonstrated in vitro in macrophage lines ${ }^{(4,11,24)}$.

An increased incidence of gastrointestinal carcinoma has been reported for patients with long-term $\mathrm{CD}^{(13,16)}$; the risk of this complication is 60 times higher in colorectal forms of the disease compared to the general population ${ }^{(19)}$.

Expression of COX-2 induced by wild-type p53 is considered to be a determinant for this immunoexpression ${ }^{(12)}$. On the other hand, overexpression of COX-2 in epithelial cells as a consequence of inflammation leads to increased levels of bcl-2 and resistance to apoptosis ${ }^{(35,39)}$.

p53, encoded by the tumor suppressor gene TP53 ${ }^{(31,33)}$, is a nuclear phospholipoprotein that controls cell cycle passage from the $\mathrm{G} 0 / \mathrm{G} 1$ to the $\mathrm{S}$ phase ${ }^{(25)}$, regulating cell growth and proliferation $^{(8,27)}$, by facilitating DNA repair during replication ${ }^{(22,25)}$ or inducing apoptosis. Protein p53 is called the guardian of the genome because it prevents the propagation of genetically injured cells ${ }^{(25,26,27,33)}$. Mutations in the p53 gene significantly alter its activity of tumor suppression regulation ${ }^{(31)}$. In patients with $\mathrm{CD}$, increased proliferation of epithelial cells, overexpression of p53 and a reduction in the expression of p21 predispose the small bowel mucosa to dysplasia and the development of carcinoma $^{(40)}$. Mutations in p53 and c-Ki-ras are frequent in long-term intestinal inflammatory disease, increasing the risk of malignant transformation ${ }^{(14)}$. In view of the lack of studies evaluating the role of COX $-1, \mathrm{COX}-2$ and $\mathrm{p} 53$ in $\mathrm{CD}$, we investigated the immunoexpression of these proteins in Crohn's ileocolitis and its correlation with clinical and histopathological parameters.

\section{METHODS}

The immunoexpression of COX-1, COX-2 and p53 in CD was analyzed in 45 paraffin-embedded biopsies obtained from the archives of the Department of Pathology, Federal University of São Paulo, "Escola Paulista de Medicina", São Paulo, SP, Brazil, comprising the period between 1996 and 2004. For comparison with another inflammatory colitis, 16 paraffinembedded biopsies were randomly selected from patients with actinic colitis (diseased-control group). Morphologically normal large bowel fragments obtained from 11 patients submitted to exploratory laparotomy for gunshot wounds were used as controls (normal-control group). Sociodemographic (gender, race, age) and clinical variables (duration of symptoms, location, duration of the disease since the time of biopsy) were collected from the records of the patients.

The presence or absence of the following parameters was semi-quantitatively evaluated on hematoxylin-eosin-stained slides: architecture: focal or diffuse crypt architecture irregularity; atrophy; chronic inflammation: focal, diffuse superficial or diffuse transmural inflammation; polymorph inflammation; epithelial changes: erosion/ulceration; mucin depletion; Paneth's cells; epithelial associated changes; increased intraepithelial lymphocytes and increased subepithelial collagen ${ }^{(2)}$.

The streptavidin-biotin-peroxidase method was used for the immunohistochemical detection of COX-1, COX-2 and p53 in the 72 cases. The following antibodies were used: mouse antihuman COX-1 monoclonal IgG antibody (cat. No. 160110, Cayman Chemical, USA) diluted 1:120, mouse anti-human COX-2 monoclonal IgG antibody (cat. No. 160112, Cayman Chemical) diluted 1:100, and mouse anti-human p53 monoclonal antibody (Dako, Denmark) diluted 1:100.

A score system based on the intensity of the reaction and the extent of staining was used for the evaluation of COX-1 and COX-2 expression. The staining intensity was scored as 1 $=$ weak, $2=$ moderate and $3=$ strong. The extent of the positive area was classified as $0=$ less than $10 \%, 1=10 \%$ to $40 \%$, $2=40 \%$ to $70 \%$, and $3=$ more than $70 \%$. Cases presenting no staining were considered to be negative. The results were classified on a scale ranging from 0 to 6 according to the sum of points obtained for staining intensity and extent. Reactions presenting a score $>3$ were considered to be positive and those presenting a score $\leq 3$ were classified as negative, according XIONG et al. ${ }^{(43)}$.

The intensity of p53 staining was classified as strong $(++)$, weak $(+)$ or absent $(0)$, and the extent of staining of the cells was scored as strong $(++)$ when more than $20 \%$ of cells were reactive and as weak $(+)$ when less than $20 \%$ of cells were positive, according NAGASHIMA et al. ${ }^{(30)}$.

The Mann-Whitney test was used for the evaluation of the variation between the different groups. The correlation of quantitative or semiquantitative variables (histological parameter scores) between groups was determined using Spearman's correlation coefficient. The data were analyzed using the Prism 3.0 (Graph $\mathrm{Pad}$, Inc.) software, adopting a level of significance of $0.05(\alpha=$ $5 \%)$. Descriptive levels $(P)$ lower than this value were considered to be significant and are represented by an asterisk.

\section{RESULTS}

In the $\mathrm{CD}$ group, $60 \%$ of the patients were females and most were white $(75.5 \%)$, ranging in age from 19 to 79 years (mean of 42 years). The terminal ileum was the site most frequently affected $(44.5 \%)$, followed by the ileum $(33.3 \%)$, colon $(20 \%)$ and duodenum-ileum $(2.2 \%)$. The mean duration of the disease was 5 years (range: 1 to 21 years).

Mild crypt distortion was the most frequent alteration (57.8\%), followed by moderate crypt distortion (35.6\%) and atrophy $(6.6 \%)$. With respect to chronic inflammation, $46.7 \%$ of the patients presented mild inflammation. Acute inflammatory activity was observed in most cases (93.3\%). Epithelial alterations (Figures 1,2 ) included ulceration in $24.4 \%$ of cases, mucin depletion in $37.8 \%$, and the presence of Paneth's cells in $24.4 \%$. With respect to associated epithelial alterations, increased intraepithelial 


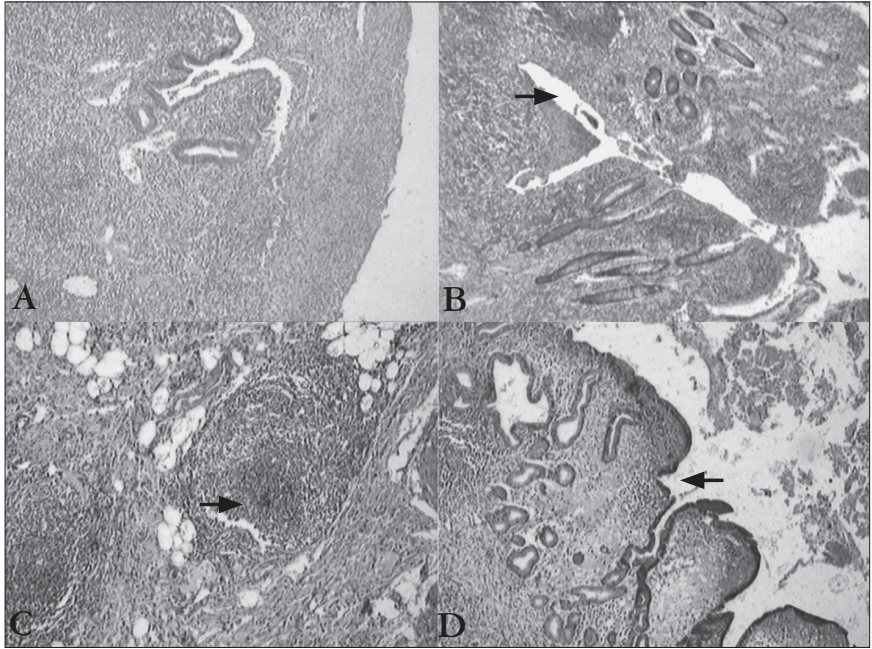

FIGURE 1. Morphological features of patients with CD. A - ulcer covered by crust (H-E; 40x); B - deep fissure up to the muscular wall (H-E; 40x) C - hyperplastic lymphoid follicles (arrow) (H-E; 40x); D - glandular atrophy and rectification of the mucous surface $(\mathrm{H}-\mathrm{E} ; 40 \mathrm{x})$

lymphocytes were observed in $93.3 \%$ of the samples and increased subepithelial collagen in $6.7 \%$.

COX-1 immunoexpression in epithelial and inflammatory cells was observed in $26.7 \%$ and $13.3 \%$ of cases, respectively. With respect to the possible association between immunohistochemical findings and sociodemographic parameters, a significant correlation was observed between $\mathrm{COX}-2$ reactivity and age $\leq 40$ years $(P=0.049)$. COX-2 reactivity in inflammatory and epithelial cells tended to be different $(P=0.0877)$. There was a significant association between COX-2 immunoexpression in inflammatory cells $(P<0.001)$ and epithelial histopathological changes $(P<0.001)$.

Comparison of immunoexpression in epithelial cells between the three groups revealed $26.7 \%$ and $62.2 \%$ positivity for COX-1 and COX-2, respectively, in the CD group (Figure $3 \mathrm{~A}-\mathrm{D}), 31.3 \%$ and $37.5 \%$ in the actinic colitis group, and $9.1 \%$ and $63.6 \%$ in the control group.

COX-1 positivity in inflammatory cells was observed in $13.3 \%$ of $\mathrm{CD}$ cases and in $18.7 \%$ of actinic colitis samples, whereas this protein was not expressed in the control group. Positivity for COX-2 was observed in $44.4 \%$ of CD samples and in $12.5 \%$ of actinic colitis samples, and no reactivity was detected in control samples. The CD group presented a significantly higher proportion of cases with COX-2 expression in inflammatory cells compared to the other groups $(P<0.001)$.

Overall analysis of all COX-1- and COX-2-immunoreactive epithelial and inflammatory cells in the three groups revealed a higher proportion of COX-2-immunoreactive cells in the CD group compared to the other groups $(P<0.001)$ (Table 1$)$.

No p53 reactivity was observed in all cases.

\section{DISCUSSION}

SINGER et al. ${ }^{(36)}$, studying the immunoexpression of COX-1 and COX-2 in ulcerative proctocolitis, $\mathrm{CD}$ and normal epithelial

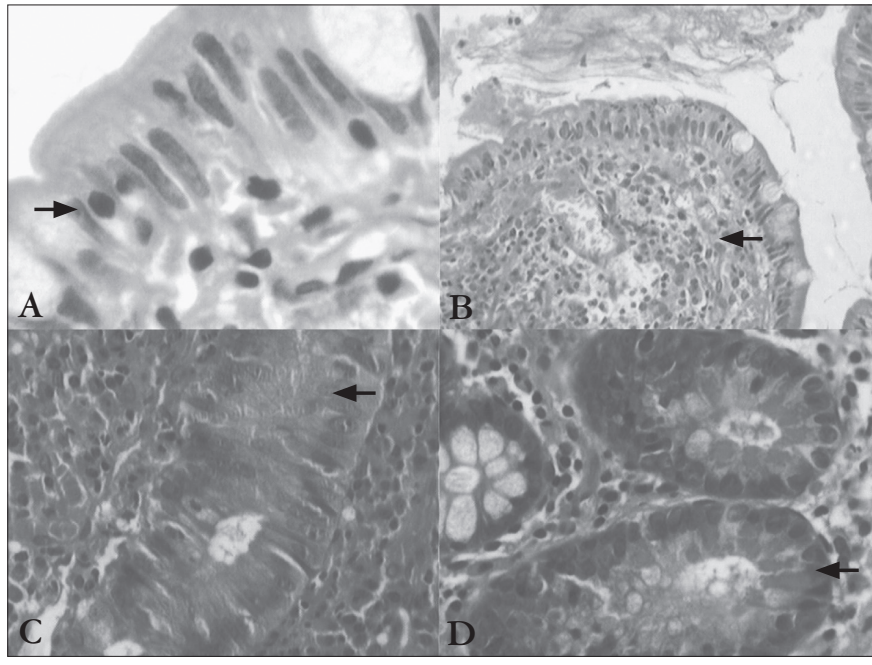

FIGURE 2. Morphological features of patients with CD. A-B - increased number of lymphocytes in the epithelial and lamina propria (H-E; 40x); C - depletion of glandular epithelial mucin (arrow) (H-E; 400x); D - Paneth's cells in tubular crypt base (arrow) (H-E; 400x) (H-E; 200x)

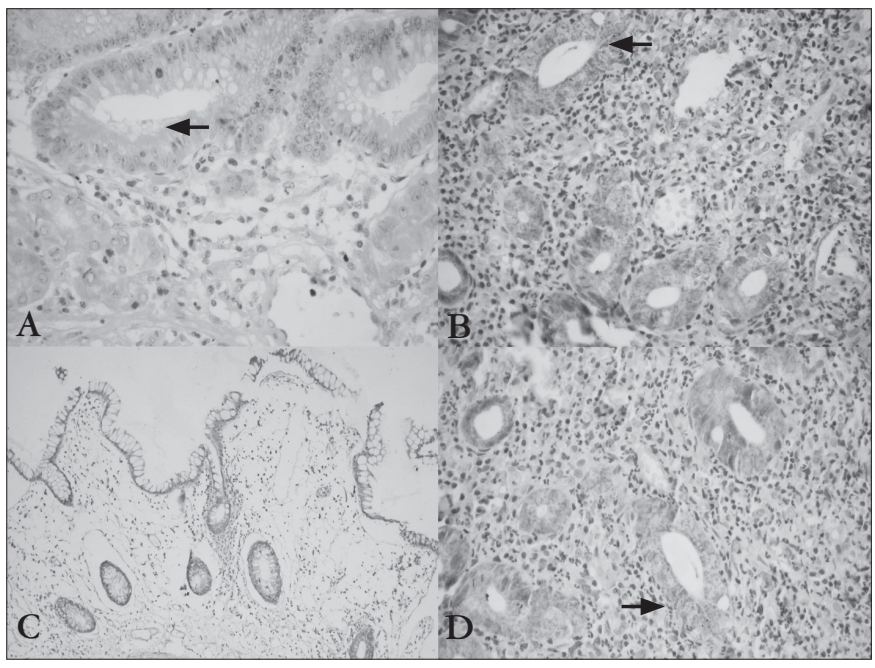

FIGURE 3. COX-1 and COX-2 immunoexpression in epithelial cells of the CD group (arrows). A - COX-1, 1+ pattern (200x); B - COX-1, $3+$ pattern (100x); C - COX-2, 2+ pattern (40x); D - COX-2, 3+ pattern $(100 x)$

tissues, observed COX-1 immunoexpression in epithelial cells and in mononuclear cells of the lamina propria at the same proportion in the three tissues analyzed. Furthermore, the authors found a higher immunoexpression of COX-2 in ulcerative proctocolitis and $C D$, suggesting that the persistent expression of this protein in the colonic epithelium of these diseases is related to an increased risk of carcinogenesis.

Although the mechanism whereby COX-2 contributes to the development of cancer is not understood, studies suggest that an increase in the expression of this protein as a consequence of inflammation reduces apoptosis and increases angiogenesis, thus creating a favorable environment for tumor growth $^{(10,13,32,38)}$. 
TABLE 1. COX-1 and COX-2 immunoexpression in epithelial and inflammatory cells. Comparison between Crohn's disease, actinic colitis and normal control group $(\mathrm{CD}, \mathrm{AC}, \mathrm{CG})$

\begin{tabular}{|c|c|c|c|c|}
\hline \multirow{3}{*}{ Variable } & \multicolumn{3}{|c|}{ Groups } & \\
\hline & CD & AC & CG & \\
\hline & $(n=45)$ & $(\mathrm{n}=16)$ & $(\mathrm{n}=11)$ & \\
\hline \multicolumn{5}{|c|}{ Epithelial cells $-\mathrm{COX}-1-\mathrm{n}(\%)$} \\
\hline negative $(<2)$ & $33(73.3)$ & $11(68.7)$ & $10(90.9)$ & \multirow[b]{2}{*}{$P>0.05$} \\
\hline positive $(\geq 3)$ & $12(26.7)$ & $5(31.3)$ & $1(9.1)$ & \\
\hline \multicolumn{5}{|c|}{ Epithelial cells $-\mathrm{COX}-2-\mathrm{n}(\%)$} \\
\hline negative $(<2)$ & $17(37.8)$ & $10(62.5)$ & $4(36.5)$ & \multirow[b]{2}{*}{$P>0.05$} \\
\hline positive $(\geq 3)$ & $28(62.2)$ & $6(37.5)$ & $7(63.7)$ & \\
\hline \multicolumn{5}{|c|}{ Inflammatory cells COX-1 - n(\%) } \\
\hline negative $(<2)$ & $39(86.7)$ & $13(81.3)$ & $11(100.0)$ & \multirow[b]{2}{*}{$P>0.05$} \\
\hline positive $(\geq 3)$ & $6(13.3)$ & $3(18.7)$ & $0(0.0)$ & \\
\hline \multicolumn{5}{|c|}{ Inflammatory cells COX-2 $-\mathrm{n}(\%)$} \\
\hline negative $(<2)$ & $25(55.5)$ & $14(87.5)$ & $11(100.0)$ & \multirow[b]{2}{*}{$P<0.001$} \\
\hline positive $(\geq 3)$ & $20(44.5)$ & $2(12.5)$ & $0(0.0)$ & \\
\hline
\end{tabular}

In the present study, low or no expression of COX-1 was observed in the $\mathrm{CD}$, actinic colitis and control groups, in agreement with the study of HENDEL and NIELSEN ${ }^{(15)}$. In contrast, JACKSON et al. ${ }^{(17)}$ demonstrated increased expression of COX-1 in the ulcerated borders of the gastric mucosa.

Comparison of the three groups showed a difference in COX-2 immunoexpression in inflammatory cells, with the CD group presenting a higher proportion of positive cases compared to the other groups. This result is correlated with one of the characteristics of the disease, i.e., the presence of marked inflammatory activity.

Some investigators have reported the absence of COX-2 immunostaining in normal epithelium ${ }^{(20,21,28,36)}$. Our results agree with those reported by JACKSON et al. ${ }^{(17)}$ who observed COX-2 expression in normal gastric mucosa. Analysis of COX-2 immunoexpression showed elevated reactivity for this protein in epithelial cells in $62.2 \%$ of CD cases and in $37.5 \%$ of actinic colitis samples.

RIBARDO et al. ${ }^{(34)}$ reported high levels of phospholipaseactivating protein, $\mathrm{COX}-2$ and phospholipids in biopsies from patients presenting an inflammatory process in the intestinal mucosa. TABERNERO et al. ${ }^{(37)}$, evaluating the expression of COX-2 in biopsies from patients with intestinal inflammatory disease, detected COX-2 positivity in the arterial wall of all cases, suggesting that this protein possibly exerts a vasoconstrictor effect on the mesenteric arteries of patients with CD. In vitro expression of COX-2 was demonstrated by JEFFERS et al. ${ }^{(18)}$ in a study investigating the activity of fibroblast growth factor (FGF) in experimental models, indicating that the therapeutic activity of FGF-20 is a promising candidate for the treatment of intestinal inflammatory disease.

\section{CONCLUSIONS AND PERSPECTIVES}

The present study indicated that the elevated immunoexpression of COX-2 in CD possibly plays a role in the pathogenesis of inflammation, consequently, the in situ study of prostaglandins such as $\mathrm{PGD}_{2}, \mathrm{PGI}_{2}$ (prostacyclins), $\mathrm{PGE}_{2}, \mathrm{PGF}_{2}$ and $\mathrm{TXA}_{2}$ in $\mathrm{CD}$ may provide important information regarding their biological effects on the pathogenesis of the disease. These future studies may permit the development of anti-inflammatory drugs directed at specific targets, such as the blockade of the metabolism of arachidonic acid at the phospholipase $\mathrm{A}_{2}$ level along the biosynthesis of eicosanoids.

In addition, the absence of epithelial dysplasia in the $\mathrm{CD}$ cases analyzed was correlated with the lack of expression of $\mathrm{p} 53$. 
Romero M, Artigiani R, Costa H, Oshima CTF, Miszputen S, Franco M. Avaliação da imunoexpressão de COX-1, COX-2 e p53 na doença de Crohn. Arq Gastroenterol. 2008;45(4):295-300.

RESUMO - Racional - A doença de Crohn, junto com a colite ulcerativa idiopática ou inespecífica constituem a doença inflamatória intestinal. A imunoexpressão de ciclooxigenase 2 (COX-2) na doença de Crohn acentua-se com a progressão da doença, enquanto que a presença do tipo selvagem de p53 suprime a transcrição de COX-2. Objetivos - Investigar a imunoexpressão de ciclooxigenase 1 (COX-1), COX-2 e p53 na doença de Crohn e correlacionar os achados com parâmetros clínico-histopatológicos. Métodos - Foram estudados 45 casos de doença de Crohn (grupo teste), 16 casos de colite actínica (grupo controledoente) e 11 casos sem história de doença intestinal (grupo controle normal). A avaliação histopatológica foi feita com lâminas coradas pela hematoxilinaeosina e a imunoexpressão de COX-1, COX-2 e p53 foi avaliada por imunoistoquímica, pelo método da estrepto-avidina-biotina-peroxidase. Resultados - Entre os pacientes com doença de Crohn, 60\% eram do sexo feminino e 40\% do masculino, 75,5\% brancos e 25,5\% não-brancos. A doença comprometia o íleo terminal em $44,5 \%$ dos casos, íleo em 33,3\%, cólon em 20\% e duodeno-íleo em 2,2\%. Associação significante foi detectada entre a imunoexpressão de COX-2 e pacientes com $\leq 40$ anos. A histopatologia dos casos de doença de Crohn mostrou distorção críptica em grau leve ou moderado ( $57,8 \%$ e $35,6 \%$ dos casos), atrofia (6,6\%), inflamação focal, difusa superficial e difusa transmural (46,7\%, 26,7\% e 20\%), inflamação aguda neutrofílica (93,3\%), alterações epiteliais: ulceração (24,4\%), depleção de mucina (37,8\%), células de Paneth (24,4\%); alterações epiteliais associadas: linfócitos intra-epiteliais (93,3\%) e colágeno subepitelial (6,7\%). No grupo doença de Crohn, imunoexpressão de COX-1, em células epiteliais e inflamatórias foi observada em 26,7\% e 22,2\% dos casos, respectivamente. Imunoreatividade de COX-2 foi detectada em células epiteliais em 68,9\% dos casos e, em células inflamatórias, em 46,7\%. Diferença marginal na reatividade de COX-2 foi observada entre as células epiteliais e inflamatórias com atividade inflamatória aguda e aumento do número de linfócitos intra-epiteliais. A comparação dos dados entre os três grupos (doença de Crohn, colite actínica de controles normais) revelou proporção maior de casos de imunoreatividade de COX-2 em células inflamatórias no grupo doença de Crohn. Imunoexpressão de p53 não foi detectada em todos os casos. Conclusão - 1) Imunoexpressão de COX-2 é elevada em doença de Crohn, sugerindo seu possível papel na patogenia do processo inflamatório da doença; 2) A ausência de displasia epitelial em todos os casos de doença de Crohn correlaciona-se com a não-expressão de p53.

DESCRITORES - Ciclooxigenase 1. Ciclooxigenase 2. Genes p53. Doença de Crohn.

\section{REFERENCES}

1. Baksh FK, Finkelstein SD, Ariyanayagam-Baksh SM, Swalsky PA, Klein EC, Dunn JC. Absence of Mycobacterium avium subsp. paratuberculosis in the microdissected granulomas of Crohn's disease. Mod Pathol. 2004;17:1289-94.

2. Bentley E, Jenkins D, Campbell F, Warren B. How could pathologists improve the initial diagnosis of colitis? Evidence from an international workshop. J Clin Pathol. 2002;55:955-60.

3. Calich VLG, VAZ CAC. Imunologia básica. São Paulo: Artes Médicas; 1989.

4. Chandrasekharan NV, Dai H, Roos KL, Evanson NK, Tomsik J, Elton TS, Simmons DL. COX-3, a cyclooxygenase-1 variant inhibited by acetaminophen and other analgesic/ antipyretic drugs: cloning, structure, and expression. Proc Natl Acad Sci USA. 2002; 99:13926-31.

5. Deininger MH, Weller M, Streffer J, Mittelbronn M, Meyermann R. Patterns of cyclooxygenase-1 and -2 expression in human gliomas in vivo. Acta Neuropathol. 1999;98:240-4.

6. Delporte C, Backhouse N, Erazo S, Negrete R, Vidal P, Silva X, Lopez-Perez JL, Feliciano AS, Munoz O. Analgesic-antiinflammatory properties of Proustia pyrifolia. J Ethnopharmacol. 2005;99:119-24.

7. Dubinsky MC, Ofman JJ, Urman M, Targan SR, Seidman EG. Clinical utility of serodiagnostic testing in suspected pediatric inflammatory bowel disease. Am J Gastroenterol. 2001;96:758-65.

8. Finlay CA, Hinds PW, Levine AJ. The p53 proto-oncogene can act as a suppressor of transformation. Cell. 1989;57:1083-93.

9. Fiocchi C. Inflammatory bowel disease: new insights into mechanisms of inflammation and increasingly customized approaches to diagnosis and therapy. Curr Opin Gastroenterol. 2004;20:309-10.

10. Gately S. The contributions of cyclooxygenase- 2 to tumor angiogenesis. Cancer Metastasis Rev. 2000;19:19-27.

11. Gilroy DW, Tomlinson A, Willoughby DA. Differential effects of inhibition of isoforms of cyclooxygenase (COX-1, COX-2) in chronic inflammation. Inflamm Res. 1998;47:79-85.

12. Han JA, Kim JI, Ongusaha PP, Hwang DH, Ballou LR, Mahale A, Aaronson SA, Lee SW. P53-mediated induction of Cox-2 counteracts p53- or genotoxic stress-induced apoptosis. Embo J. 2002;21:5635-44.
13. Harris RE. Cyclooxygenase-2 (cox-2) and the inflammogenesis of cancer. Subcell Biochem. 2007;42:93-126.

14. Heinzlmann M, Lang SM, Neynaber S, Reinshagen M, Emmrich J, Stratakis DF, Heldwein W, Wiebecke B, Loeschke K. Screening for p53 and K-ras mutations in whole-gut lavage in chronic inflammatory bowel disease. Eur J Gastroenterol Hepatol. 2002;14:1061-6.

15. Hendel J, Nielsen OH. Expression of cyclooxygenase-2 mRNA in active inflammatory bowel disease. Am J Gastroenterol. 1997;92:1170-3.

16. Itzkowitz SH, Harpaz N. Diagnosis and management of dysplasia in patients with inflammatory bowel diseases. Gastroenterology. 2004;126:1634-48.

17. Jackson LM, Wu KC, Mahida YR, Jenkins D, Hawkey CJ. Cyclooxygenase (COX) 1 and 2 in normal, inflamed, and ulcerated human gastric mucosa. Gut. 2000;47:76270 .

18. Jeffers M, McDonald WF, Chillakuru RA, Yang M, Nakase H, Deegler LL, Sylander ED, Rittman B, Bendele A, Sartor RB, Lichenstein HS. A novel human fibroblast growth factor treats experimental intestinal inflammation. Gastroenterology. 2002;123:1151-62.

19. Jess T, Winther KV, Munkholm P, Langholz E, Binder V. Intestinal and extra-intestinal cancer in Crohn's disease: follow-up of a population-based cohort in Copenhagen County, Denmark. Aliment Pharmacol Ther. 2004;19:287-93.

20. Joo YE, Oh WT, Rew JS, Park CS, Choi SK, Kim SJ. Cyclooxygenase-2 expression is associated with well-differentiated and intestinal-type pathways in gastric carcinogenesis. Digestion. 2002;66:222-9.

21. Joo YE, Rew JS, Seo YH, Choi SK, Kim YJ, Park CS, Kim SJ. Cyclooxygenase-2 overexpression correlates with vascular endothelial growth factor expression and tumor angiogenesis in gastric cancer. J Clin Gastroenterol. 2003;37:28-33.

22. Kastan MB, Onyekwere O, Sidransky D, Vogelstein B, Craig RW. Participation of p53 protein in the cellular response to DNA damage. Cancer Res. 1991;51(23 Pt 1): 6304-11.

23. Khan AA, Iadarola M, Yang HY, Dionne RA. Expression of COX-1 and COX-2 in a clinical model of acute inflammation. J Pain. 2007;8:349-54.

24. Kis B, Snipes JA, Busija DW. Acetaminophen and the cyclooxygenase-3 puzzle: sorting out facts, fictions, and uncertainties. J Pharmacol Exp Ther. 2005;315:1-7.

25. Kressner U, Inganas M, Byding S, Blikstad I, Pahlman L, Glimelius B, Lindmark G. Prognostic value of p53 genetic changes in colorectal cancer. J Clin Oncol. 1999; 17:593-9. 
26. Lane DP. Cancer. p53, guardian of the genome. Nature. 1992;358:15-6.

27. Levine AJ, Momand J, Finlay CA. The p53 tumour suppressor gene. Nature. 1991;351:453-6.

28. Ling FC, Baldus SE, Khochfar J, Xi H, Neiss S, Brabender J, Metzger R, Drebber U, Dienes HP, Bollschweiler E, Hoelscher AH, Schneider PM. Association of COX-2 expression with corresponding active and chronic inflammatory reactions in Barrett's metaplasia and progression to cancer. Histopathology. 2007;50:203-9.

29. Loftus EV Jr. Clinical epidemiology of inflammatory bowel disease: incidence, prevalence, and environmental influences. Gastroenterology. 2004;126:1504-17.

30. Nagashima F, Boku N, Ohtsu A, Yoshida S, Hasebe T, Ochiai A, Sakata Y, Saito H, Miyata Y, Hyodo I, Ando M. Biological markers as a predictor for response and prognosis of unresectable gastric cancer patients treated with irinotecan and cisplatin. Jpn J Clin Oncol. 2005;35:714-9.

31. Nigro JM, Baker SJ, Preisinger AC, Jessup JM, Hostetter R, Cleary K, Bigner SH, Davidson N, Baylin S, Devilee P, et al. Mutations in the p53 gene occur in diverse human tumour types. Nature. 1989;342:705-8.

32. Ohno S, Ohno Y, Suzuki N, Soma G, Inoue M. Cyclooxygenase-2 expression correlates with apoptosis and angiogenesis in endometrial cancer tissue. Anticancer Res. 2007;27(6A):3765-70.

33. Onel K, Cordon-Cardo C. MDM2 and prognosis. Mol Cancer Res. 2004;2:1-8.

34. Ribardo DA, Crowe SE, Kuhl KR, Peterson JW, Chopra AK. Prostaglandin levels in stimulated macrophages are controlled by phospholipase A2-activating protein and by activation of phospholipase C and D. J Biol Chem. 2001;276:5467-75.

35. Sakamoto T, Uozaki H, Kondo K, Imauchi Y, Yamasoba T, Sugasawa M, Kaga K. Cyclooxygenase- 2 regulates the degree of apoptosis by modulating bcl-2 protein in pleomorphic adenoma and mucoepidermoid carcinoma of the parotid gland. Acta Otolaryngol. 2005;125:191-5.
36. Singer, II, Kawka DW, Schloemann S, Tessner T, Riehl T, Stenson WF. Cyclooxygenase 2 is induced in colonic epithelial cells in inflammatory bowel disease. Gastroenterology. 1998;115:297-306.

37. Tabernero A, Reimund JM, Chasserot S, Muller CD, Andriantsitohaina R. Cyclooxygenase-2 expression and role of vasoconstrictor prostanoids in small mesenteric arteries from patients with Crohn's disease. Circulation. 2003;107:1407-10.

38. Tsujii M, DuBois RN. Alterations in cellular adhesion and apoptosis in epithelial cells overexpressing prostaglandin endoperoxide synthase 2. Cell. 1995;83:493-501.

39. Tsujii M, Kawano S, Tsuji S, Sawaoka H, Hori M, DuBois RN. Cyclooxygenase regulates angiogenesis induced by colon cancer cells. Cell. 1998;93:705-16.

40. Uesugi H, Mitomi H, Sada M, Takahashi H, Kobayashi K, Igarashi M, Katsumata T, Ihara A, Ohtani Y, Ikeda S, Okayasu I. A case of adenocarcinoma of the small intestine in a Japanese patient with Crohn disease: a report with immunohistochemical and oncogenic analyses. Scand J Gastroenterol. 1999;34:1162-7.

41. Vane JR, Bakhle YS, Botting RM. Cyclooxygenases 1 and 2. Annu Rev Pharmacol Toxicol. 1998;38:97-120.

42. Wang YF, Zhang H, Ouyang Q. Clinical manifestations of inflammatory bowel disease east and West differences. J Dig Dis. 2007;8:121-7.

43. Xiong B, Sun TJ, Hu WD, Cheng FL, Mao M, Zhou YF. Expression of cyclooxygenase-2 in colorectal cancer and its clinical significance. World J Gastroenterol. 2005;11:1105-8.

44. Yu Y, Fan J, Hui Y, Rouzer CA, Marnett LJ, Klein-Szanto AJ, FitzGerald GA, Funk $\mathrm{CD}$. Targeted cyclooxygenase gene (ptgs) exchange reveals discriminant isoform functionality. J Biol Chem. 2007;282:1498-506.

Recebido em 17/12/2007. Aprovado em 13/6/2008 